\title{
North African Origins in and of the French Republic
}

The Republic makes no distinction among its children.

- MANUEL VALLS, FORMER FRENCH PRIME MINISTER ${ }^{1}$

Look at the Gare du Nord. ${ }^{2}$ You no longer have the impression of being in France, you have the impression of being in Africa. No, really... You arrive at Gare du Nord, it's Africa, it's no longer France. We don't have the right to say that, but I'll say it because it's true.

-NADINE MORANO, LES RÉPUBLICAINS PARTY POLITICIAN ${ }^{3}$

A tall, muscular man with tousled dark brown hair, Abdelkrim met me one afternoon in March of 2009 at a Starbucks in the quartier (neighborhood) of Montparnasse and told me he identifies with Bruce Lee, the Hong Kong-American martial artist and action-film star. "He was too American for the Chinese and too Chinese for Americans," he explained between sips of his espresso. ${ }^{4.5}$ Despite his successes, Bruce Lee was caught between American and Chinese cultures, and never considered as belonging to either. Abdelkrim completely relates to this dualism; he too feels that he is too French for Maghrébins and too maghrébin for the French. ${ }^{6}$

Abdelkrim similarly told me about reading The Autobiography of Malcolm X as a teenager, and how Malcolm's struggles to be accepted as a black man in white America deeply resonate with him. A thirty-two-year-old with dual French and Algerian citizenship, Abdelkrim boasts that he was born in the same town in central France, Châteauroux, as French actor Gérard Depardieu and is just as French as Depardieu is.

The story of Abdelkrim's parents' immigration to France from Algeria is distinctive when compared with that of other North African immigrants. Whereas many maghrébin immigrants came to France primarily for economic reasons in the immediate postcolonial period, Abdelkrim's parents, who are bilingual in French and Arabic, came for political ones. They arrived in the late 1960s from Algiers, 
the capital city of Algeria, after the nation won its independence from France in 1962. His father was active in the Front de libération nationale, a socialist political party fighting for Algerian independence. After the war, he became disenchanted with living in Algeria because of the instability in the country brought about by Algeria's new political system. He eventually married Abdelkrim's mother and had five children, and the entire family then immigrated to France. Abdelkrim's father became a maintenance worker at a habitation à loyer modéré (subsidized housing, or HLM) complex, and his mother was a homemaker. They had three additional children after immigrating to France-including Abdelkrim, who is the youngest of the eight. Abdelkrim grew up in a Muslim household, and though as an adult he celebrates Ramadan with his family, he does not otherwise engage in Muslim practices. He also believes religion should be a private affair, per French Republican ideology.

When Abdelkrim was growing up, his parents actively engaged with his schooling and communicated with his teachers, thanks to their fluency in French. Though neither attended school past the age of fourteen, they engaged in self-education afterward. In their predominately immigrant neighborhood, it was Abdelkrim's parents who helped neighborhood residents who could not read or write with their "daily round" (Logan and Molotch 1987), whether it was going to doctor's appointments or having conferences with teachers.

In this context, Abdelkrim does not remember feeling particularly different from others because of his maghrébin origins growing up, until he attended a middle school outside his neighborhood, where there were fewer nonwhites and immigrant-origin individuals. "That is when everything changed," he recalls, "You discovered others and they discovered you. And we didn't have the same life." Sometimes he became friends with people different from him; oftentimes he did not. As Abdelkrim had more and more interactions with people outside his neighborhood, his visibility as a maghrébin-origin individual and how that marked him as different became increasingly apparent to him. Growing up as a nonwhite person in France, Abdelkrim has since struggled to come to terms with his identity.

He later attended a university in Tours, a town in central France's Loire valley, to please his mother, who wanted him to become a lawyer. He remembers there being only two other ethnic minorities there and feeling he had to stick with them to survive. On two separate occasions, he was physically attacked and called ethnic slurs by other students. Abdelkrim eventually left law school and has since become an accomplished freelance journalist, which he feels is his calling.

Still, despite his successes and his attainment of a middle-class status, he finds that many of his fellow citizens do not accept him as French. He usually has an acute sense of being French only when he is traveling internationally, as opposed to when he is in France. He remembers traveling to London when he was twentyfour years old and meeting some African Americans. Upon telling them that he 
was maghrébin and Algerian, they informed him that he was French. "They just kept telling me that I am from France, so I am French," he recalled. It seemed so logical to them, yet this logic is not so easily accepted in French society.

This disconnect between where he was born and how he is perceived is the reality for racial and ethnic minorities born in France to immigrant parents.

And that is the subject of this book, Citizen Outsider: Children of North African Immigrants in the France. Based on ethnographic research, including interviews, in the Paris metropolitan area, I address the following questions: How do ethnic minorities in France contend with implicitly race-based definitions of what it means to be French? How do upwardly-mobile and middle-class maghrébinorigin individuals perceive the possibilities for participating fully in the French mainstream? Decades after the end of France's brutal colonial empire in the North African countries of Algeria, Tunisia, and Morocco, what is the legacy of this empire for the immigrant-origin population, born and raised in France to parents who emigrated for better opportunities, and what are the everyday sociopolitical realities it faces? How do individuals who are citizens remain on the margins of mainstream society, and what does this reveal about how race and ethnicity, including differences based on them, operate in practice?

Despite former Prime Minister Manuel Valls and other French politicians' declarations that there is no differential treatment in France, the experiences of Abdelkrim and other children of North African immigrants reveal how this conclusion is wrong. Differential treatment and exclusion are based on racial and ethnic status; individuals like Abdelkrim are marginalized because they are nonwhite. Even if Abdelkrim and others like him feel French, claiming French identity rests in the degree to which individuals perceive them as French. They hit a glass ceiling: France's imagined community (Anderson 1991) does not include them. Much research on the second generation in Europe and the United States focuses on the degree to which they are assimilated, acculturated, or integrated, particularly in terms of specific outcomes, such as educational attainment or labor force participation (Alba and Foner 2015; Alba and Waters 2011; Crul and Mollenkopf 2012; Waters 2000; Waters et al. 2010; Zhou 1997; Zhou and Lee 2007). Yet while all these terms may apply to Abdelkrim-for example, in his educational attainment and achievement of a middle-class status-he is still alienated from mainstream French society because he is nonwhite. As such, a focus on the second generation through the lens of assimilation or integration is insufficient.

This book specifically focuses on the middle-class segment of the North African second generation-those individuals who have achieved upward mobility vis-à-vis their immigrant parents. This is the first ethnographic account of this segment of the second-generation population. It connects to a growing literature on middle-class subaltern minorities worldwide. Instead of just focusing on their outcomes, particularly relating to educational attainment and employment 
patterns, I focus on their experience as an ethnic minority, including the processes embedded within that experience, in a national context that does not recognize minorities based on ethnic origin or have a language or framework for making sense of them.

In doing so, I lay to rest the notion of a French exceptionalism regarding distinctions based on race and ethnicity. I examine how a population that is legally and technically French is not considered culturally French, and is therefore excluded from popular imaginations of who a French person is. This reveals how race, ethnicity, and culture intersect in determining who is a citizen of the nation-state and who can claim a French identity.

The continually reinforced rejection by mainstream society experienced by Abdelkrim and others belies previous conclusions about the salience of race and ethnicity as markers of difference in France. By traditional measures, many children of North African immigrants, or the North African second generation, as I also refer to them, are assimilated (Portes and Zhou 1993). ${ }^{7}$ The individuals I discuss in this book were educated at French schools and universities. Their native tongue is French. They are French citizens. While their middle-class status might suggest a triumph of France's Republican model, which purports to downplay distinctions based on identity among citizens, this population's continued experiences of exclusion and discrimination challenge this straightforward conclusion.

I frame these individuals as "citizen outsiders"-a framework rooted in early works by black scholars such as Audre Lorde (2007), W. E. B. DuBois ([1903] 1994) and Frantz Fanon (1967) and recently coined by political scientist Cathy Cohen (2010) - in that they are simultaneously members of a society yet kept on the margins of that society. I further use the framework of "cultural citizenship" as a corrective to theories of immigrant incorporation and assimilation, as well as to illustrate how difference is implicitly marked among individuals without explicit designations by the state. Individuals who are technically citizens are not treated as full citizens because of their assigned otherness as racial and ethnic minorities. Members of this French-born population find that they cannot escape this assigned otherness. Because of their North African origins, they have been denied cultural citizenship, which signifies a claim to societal belonging that is accepted by others, enabling children of North African immigrants to traverse the culturalsymbolic boundaries of French identity and be considered truly French.

These individuals' marginalization reveals both how race and ethnicity remain significant in shaping life circumstances in French society and how citizenship status is not a sufficient boundary defining insiders and outsiders. Rather, acceptance as a fellow citizen is inextricably linked to boundaries around French identity marked by race and ethnicity. Despite promoting a colorblind ideology, France, at both the state level and through microlevel interactions, reinforces the 


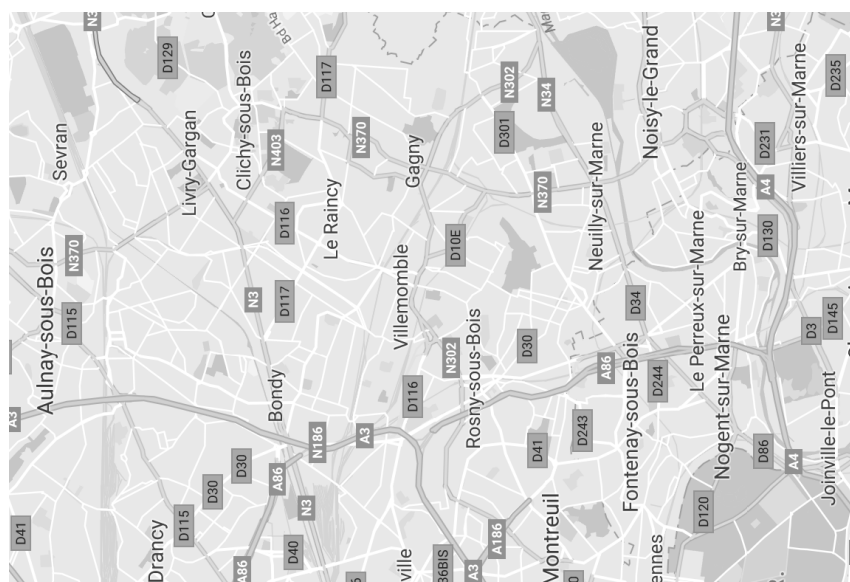

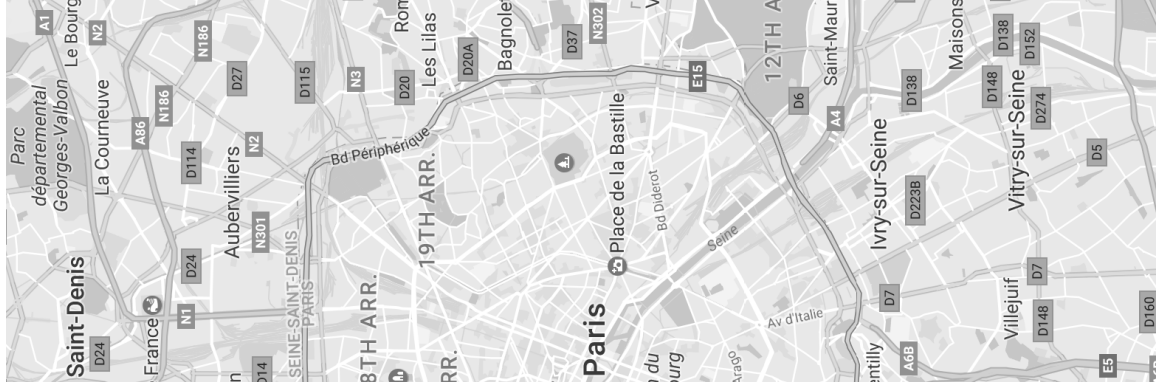

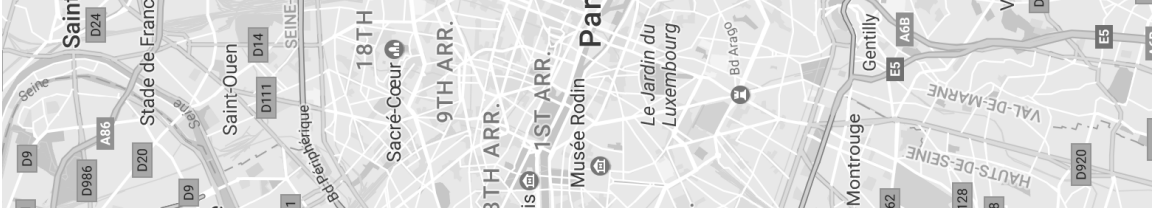

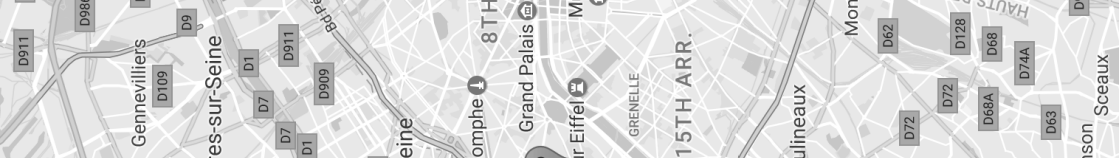

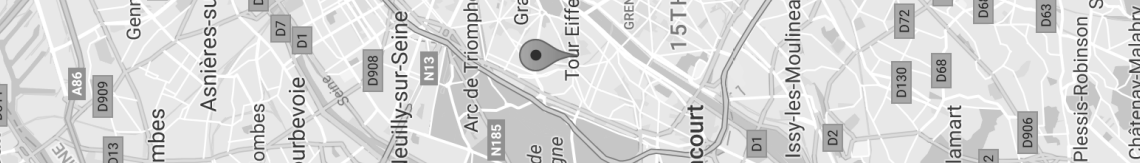

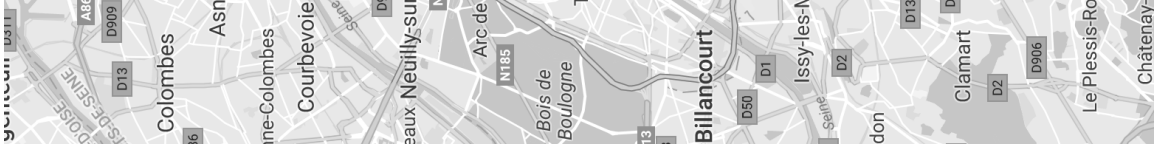

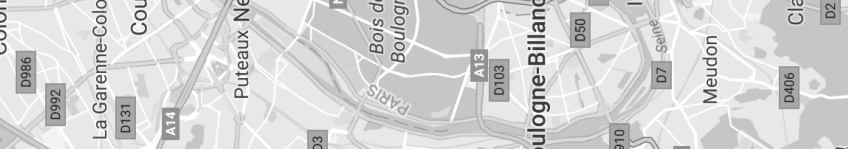

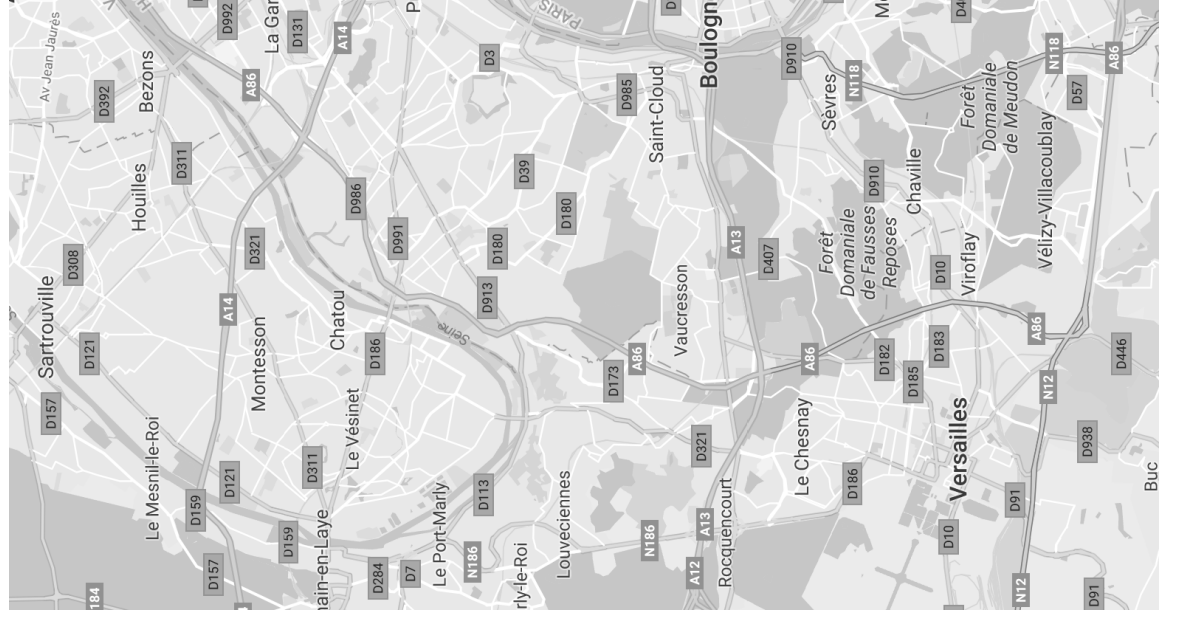


differentiation between nonwhite individuals and the rest of French society, no matter how much the North African second generation seeks to challenge that.

The question of who makes up a nation, the role of race and ethnicity in this definition, and what happens to those individuals excluded from that definition, is, of course, not limited to France. The experiences of children of North African immigrants have implications for other racial and ethnic minority populations worldwide, including, but not limited to, second-generation immigrants in the United States such as West Indians (Waters 2000) and Mexicans (Portes and Rumbaut 2001), middle-class African Americans (Carter 2005; Frazier 1957; Lacy 2007; Pattillo 2007; Pattillo-McCoy 1999), middle-class Dutch women of Surinamese descent in the Netherlands (Essed 1991), and the Turkish second generation in Western Europe (Fleischmann et al. 2011). Ultimately, for populations designated as "other" or treated as outsiders, including the North African second generation, citizenship, or being a citizen, does not sufficiently allow for traversing boundaries of full societal inclusion.

In this chapter, I present a historical background on French Republicanism and North African immigration to France that contextualizes the contemporary experiences of the middle-class adult children of North African immigrants whom I studied. I then provide an overview of our existing knowledge of the North African second generation. Next, I discuss how, despite the middle-class status of this population, its members remain marginalized because they are nonwhite. I further discuss France's "racial project" (per Omi and Winant's 1994 formulation) and how race and ethnicity operate in France, without state-level designations. Extending from this, I discuss the framework of cultural citizenship, the denial of which is evidence of France's racial project. I finally discuss the methods of this study and provide a brief overview of subsequent chapters.

\section{FROM THE MAGHREB TO FRANCE}

Despite a long history of immigration and colonialism, France rarely acknowledges that history, invoking its Republican ideology to preserve the status quo and promote a monolithic version of French identity and history (Barou 2014; Noiriel 1996; Thomas 2007). But France has never been the uniform entity that the Republican model would suggest (Chabal 2015). For example, about 25 percent of the French population has at least one parent or grandparent who immigrated to France (from any country) (Barou 2014). More recently, according to the Institut national de la statistique et des études économiques (National Institute of Statistics and Economic Studies, or INSEE), which conducts the census, as of 2014, immigrants comprise 8.6 percent of the total French population (Brutel 2015). Immigration has long been framed as a social problem that threatens French national identity (Tetreault 2013). 
Under the Republican model, France emphasizes citizenship as the connecting factor among her citizens over any other characteristic and conceives of its identity in national and civic, rather than ethnic, terms, an emphasis dating from before the French Revolution (Bell 2003). The state interacts with individuals independent of any group categorization or special interest group (Amselle 2003; Chapman and Frader 2004; Oberti 2007; Tetreault 2013). ${ }^{8}$ Republicanism in France is based on equality before the law, individual emancipation (or a rejection of communautarisme $e^{9}$ ), jus solis (based on place of birth) and jus sanguinis (based on parental origins) citizenship, laïcité, and cultural assimilation (d'Appollonia 2009).

Established by law in 1905, laïcité is the French term for the separation of church and state. ${ }^{10}$ It has often been employed to stress the assimilation of immigrantorigin individuals (Bowen 2006; Kuru 2008). The French state cannot promote any individual religion, and individuals are encouraged to keep their religious affiliations to themselves (Bowen 2004b). ${ }^{11}$ The distinction between the public and private spheres is emphasized; any difference should be relegated to the private sphere (Escafré-Dublet and Kastoryano 2012; Kastoryano and Escafré-Dublet 2012). Some scholars have noted the role that religion, particularly Catholicism, has played in the development of French Republican society (Gray 2008; Laborde 2008), despite France's emphasis on laïcité. ${ }^{12}$

Being French is supposed to supersede all other identities and identifications, including ethnic, racial, religious, linguistic, and regional. The creation of France as a nation rested in subsuming such identifications. French philosopher Ernest Renan's lecture at the Sorbonne famously asked the question, "Qu'est-ce qu'une nation?" (What is a nation?) ([1887] 1992). He emphasized the solidarity among individuals-and the sacrifices citizens make on behalf of that solidarity-over language, race, religion, or geography (Cartrite 2009). It is these commonalities that are supposed to constitute France as a nation and bring its members together. In this "indivisible" Republic, acknowledging differences regarding identity and recognizing racial and ethnic diversity threatens the disruption of the Republican model (Cooper 2014; Kastoryano and Escafré-Dublet 2012). Acknowledging difference is viewed as propagating difference. In fact, the United States is often framed as an example of this danger, in that an identity politics based on multiculturalism hinders the fostering of a unified and centralized national community (Chabal 2015).

Despite the Republican emphasis on the renunciation of racial and ethnic categorization, scholars have argued that France has long relied on racial and ethnic boundaries in constructing its national identity (Chapman and Frader 2004; Kastoryano 2004; Peabody and Stovall 2003; Wieviorka 1992). According to French historian Gérard Noiriel (1996), immigration has been an elemental feature of the construction of the distinction between "us" and "them" in the creation of the French nation. ${ }^{13}$ The Republican model, in fact, marks difference, even without 
officially acknowledging it (Chapman and Frader 2004; Fernando 2009; Laborde 2008; Schneider 2008; Wilder 2007). Moreover, French identity has long been implicitly framed as white (Constant 2009; Peabody and Stovall 2003). Ideologies of racial inferiority were used to justify France's imperialism in the Maghreb and other regions. To give one example, aristocrat Arthur de Gobineau's 1884 Essai sur l'inégalité des races humaines (Essay on the Inequality of the Human Races) asserted the biological and cultural superiority of Europeans over blacks, who were described as animal-like subjects and belonging to the lowest racial category (Thomas 2007; Winant 2001; Wright 2004). ${ }^{14}$

France's colonial empire served to reify the boundary between French and "other" and highlighted the contradictions embedded within French Republicanism (Kastoryano and Escafré-Dublet 2012). ${ }^{15}$ France's relationship with the Maghreb began with the colonization of Algeria in 1830, of Tunisia in 1831, and of Morocco in 1912. Tunisia and Morocco were French protectorates, while Algeria was considered an overseas territory of France. Tunisia and Morocco remained in French control until 1956, and Algeria remained in French control until 1962. Colonialism in the Maghreb created a differential status for those of North African origin, which has ramifications for descendants of immigrants from those French colonies today. ${ }^{16}$ North Africans were framed as culturally distinct from the French colonialists, an attitude that persists in the postcolonial period (Kastoryano and Escafré-Dublet 2012).

Though emigration from the Maghreb to France began as early as the early 190os, World War I brought immigrants from these French colonies en masse to France for work (Barou 2014; Kaya 2009). ${ }^{17}$ It was expected that these immigrants would be temporary residents (Winant 2001). In many cities, including Paris, immigrant workers settled in the outlying banlieues (suburbs), owing to the presence of cheaper housing and factory employment (Esman 2009; Stovall 2003). ${ }^{18}$ Often these immigrants "were marginalized and excluded from full participation in French society. Economically they frequently performed the dirtiest and most menial tasks; legally they were disadvantaged as they were not French citizens and therefore did not have the same rights as the French; socially and geographically they were confined to areas on the outskirts of major cities" (Silverman 1992, 46). Moreover, they were treated worse than immigrants from European countries (Barou 2014). The numbers of North African immigrants continued to increase after World War II, the end of the Fourth Republic in 1958, and the Algerian War of Independence in $1962 .{ }^{19}$ Within a decade, by the early 1970 s, there were more than 800,000 immigrants from Algeria alone (Silverstein 2008).

This growth in the number of North African immigrants saw more of them living in an HLM (subsidized housing) complex in the banlieues, as opposed to the bidonvilles (shantytowns), where they had lived previously (Dikeç 2007; Hargreaves 1996; Silverstein 2008; Weir 1993). As more and more middle-class Français 
de souche (white native French) moved from HLMs to private housing because of low-interest loans provided by the French government in the early 1970s, HLMs and banlieues became even more associated with North African and sub-Saharan African immigrant-origin individuals (Barou 2014; Simon 1998; Tissot 2008). ${ }^{20,21,22}$ Owing to an economic recession and declining employment opportunities, the French government temporarily suspended immigration of non-European lowskilled workers in 1974 (Stovall 2003). ${ }^{23}$ However, this led to migrant workers settling permanently with their families in France, as opposed to returning to their countries of origin (Barou 2014; Body-Gendrot 1993; Kaya 2009). According to INSEE, more than half of the immigrants who arrived before 1974 came for employment; one-third came to join their husbands or family. The North African second generation descended primarily from this population (Silberman et al. 2007).

Government policies and actions have targeted various aspects of the living conditions of immigrant-origin individuals. ${ }^{24}$ The presidency of Socialist François Mitterrand in 1981 saw increased immigration-related legislation (Thomas 2007). In 1981 he granted equal rights of association to immigrants (Amara 2006; BodyGendrot 1993). As a result, organizations such as SOS Racisme, an antiracist organization heavily influenced by Republican ideology, and France Plus, an activist group, were founded during the 1980s (Begag 1990; Silverman 1992). These and similar organizations were also influenced by the 1983 Marche des Beurs (also known as the March for Equality and against Racism), by children of North African immigrants from Marseille and Paris (Amara 2006; Begag 1990; Hajjat 2013).

A 1972 law banned collecting statistics related to race and ethnicity, including in the census. This law further codified the use of race-neutral policies in France and framed racism as an individual act, as seen in, for example, prohibitions against hate speech (Bleich 2004). ${ }^{25}$ Because French government policies stress formal race neutrality, they are often perceived as ineffective in addressing discrimination in areas such as education, housing, and employment (see Bleich 2001, 2003, 2004; Calves 2004; Favell 2001; Hargreaves 2004; Lieberman 2004). Because of Republican ideology, government policies target particular geographical areas instead of identity-based communities, as in the United States, creating, for example, a territorial affirmative action instead of an ethnic or race-based affirmative action (Dikeç 2007). ${ }^{26}$

Understanding the presence of Islam in France is crucial for understanding the racism and marginalization the North African-origin population faces, even if all maghrébin-origin individuals do not automatically identify as Muslim. While I discuss Muslims throughout this book, I stress the distinction between Muslims and North African-origin individuals here. While many respondents are Muslims, which impacts their everyday lives and experiences of marginalization, the fact that they are maghrébin or North African is the basis of their exclusion. 
Because of laws prohibiting categorization based on faith, statistics on Muslims in France are scarce and somewhat inconsistent (Bowen 2004C; Laurence 2001; Laurence and Vaisse 2006). Muslims are estimated to be about 6 to 8 percent of France's total population (including immigrants and those born in France) (d'Appollonia 2009; Gray 2008; Sebian 2007). France remains the country with the largest concentration of Muslims in Europe (Hargreaves et al. 2007; Keaton 2006), and most Français de confession musulmane (French Muslims) are of Algerian and Moroccan origin (Bowen 2004b; Laurence 2001). Much research on French Muslims has highlighted their heterogeneity, particularly in terms of identity and practices (which I discuss further in chapter 3, and has drawn a distinction between Muslim culture and Muslim religion or between believing versus practicing Muslims. ${ }^{27}$

Despite portrayals of French Muslims as adopting an oppositional Muslim identity and of Islam as fundamentally incompatible with French society (Foner and Alba 2008), recent research has challenged the prevailing notion of French Muslims as completely different from other French people (Klausen 2008; Laurence and Vaisse 2006), as well as the notion of Muslim status conflicting with national belonging to France (Beaman 2016; Maxwell and Bleich 2014) ${ }^{28}$ Identifying as Muslim does not pose a barrier to identifying as French (Barou 2014; Beaman 2016; Nyiri 2007). ${ }^{29}$ Whether or not they actually practice Islam or identify as practicing Muslims, North African-origin individuals are often considered or identified as Muslim by others because Islam is the major religion in their parents' country of origin (Hargreaves et al. 2007). As I discuss further in chapter 3, the marginalization that respondents experience as Muslims is emblematic of racial and ethnic exclusion, in a context in which Islam is an acceptable way to mark difference, and race and ethnicity are not. The use of Muslim as a category for maghrébin individuals is a way to subvert discussion of race and ethnicity.

The growing attention paid to immigration in France is not related to numbers, as the actual number of immigrants has remained constant since 1930, but rather to its changing demographics, as presently more immigrants are from former North African colonies than other regions (Gafaïti 2003; Noiriel 1996; Thomas 2007; Tribalat 2004a). ${ }^{30}$ Recent immigration-related developments in France reveal how national identity remains under debate and how immigrants and their descendants are continually framed as disruptive to this constructed national identity (Silverstein 2008). In 2007 then-president Nicolas Sarkozy established the Ministère de l'immigration, de l'intégration, de l'identité nationale et du développement solidaire (Ministry of Immigration, Integration, National Identity and Codevelopment). The ministry's stated goals included controlling migration flows, favoring integration, and promoting French identity, ${ }^{31}$ which illustrated how language relating to immigration and citizenship were tightened under his presidency (Barou 2014). To some, 
this ministry suggested that "immigrants don't suit French national identity. [It tells them] Integrate or else" (Green 2007). In November 2009, Sarkozy and then-minister of IIADS Eric Besson launched a public debate on French national identity, with the stated purpose of "constructing a better shared vision of what French national identity is today" and "reaffirming Republican values and pride in being French." ${ }^{32}$ This debate was criticized as a cover for anti-immigrant sentiment toward and ignorance about ethnic and religious minorities (Cowell 2009; Erlanger 2009; Erlanger 2010). ${ }^{33}$ Under controversy, IIADS was demolished in 2010 (Kastoryano and Escafré-Dublet 2012).

The complexities of nationality and citizenship status in France are crucial to understanding how postcolonial immigrants and their descendants were routinely left out of both the social and symbolic boundaries around France as a nation and French as an identity (Silverstein 2008). ${ }^{34}$ The French census classifies its populations in three categories: French by birth, French by naturalization, and foreign (Kastoryano 2004). Citizenship is based on jus solis (place of birth) rather than jus sanguinis (parental origins); however, children of foreigners have long been an exception to this rule (see Bass 2014 for overview of policies and laws for children of foreigners). Part of this is due to the historical distinction between French citizenship and nationality, as nationality does not mean automatic citizenship and all the benefits it confers. Brubaker (1992) discusses how France has a civic conception of nationhood (in contrast to Germany, which has an ethnic conception of nationhood and citizenship based on jus sanguinis).

In this book, I discuss how, despite this conception of citizenship, descendants of colonialism in the Maghreb are kept from being full members of French society. Because Algeria was a French colony, Algerians had French nationality, but they were not considered French citizens and did not have all the rights conferred to French citizens, such as voting (Noiriel 1996). ${ }^{35}$ During the period of French colonialism, Maghrébins had a second-class status because of this distinction between French nationality and French citizenship. Colonial relations therefore shaped French citizenship and belonging (Tetreault 2013). ${ }^{36}$ This second-class status continued even after the end of colonialism (Kastoryano and Escafré-Dublet 2012).

The carte d'identité (national identity card) and the code de la nationalité française (French nationality code) have served to exclude immigrants from becoming full members of French society (Noiriel 1996). The code de la nationalité has increasingly shifted toward a more restrictive definition of citizenship amid concerns over increasing immigration from North African and sub-Saharan African countries (Feldblum 1999; Silverstein 2008). ${ }^{37}$ Those born in France to maghrébin immigrants acquire "virtual citizenship at birth" (Simon 2012). They are considered foreigners at birth and generally become citizens when they are eighteen years old, or earlier by request (Bass 2014; Brubaker 1992; Keaton 2006). The French model of integration is an assimilationist one (Schnapper et al. 2003; 
Tribalat 2004a). ${ }^{38}$ Immigrants and their descendants are supposed to assimilate into France-to be and act as French as possible. Yet this is not sufficient for descendants of France's colonial empire to be included in France.

\section{THE NORTH AFRICAN SECOND GENERATION}

As questions regarding race and ethnic origin are not asked on the French census, ${ }^{39}$ there is a paucity of statistics available about children of North African immigrants (Laurence and Vaisse 2006; Schnapper et al. 2003; Simon 1999; Tribalat 2004a). A few recent large-scale quantitative studies have begun to fill this gap by combining data on individuals' country of birth and their parents' country of birth. The 1999 Etude de l'histoire familiale (Study of family history, or EHF) determined that 22 percent of France's total foreign-origin population has origins in the Maghreb and 25.9 percent of second-generation immigrants in France are of maghrébin origin (Tribalat 2004a). To be more precise, about 14 percent are of Algerian origin, 9 percent Moroccan, and 4 percent Tunisian (Borrel and Simon 2005; Tribalat 2004a)..$^{40}$

Even though this population is statistically invisible, it is socially visible. Despite being born and raised in France, the maghrébin second generation is often made to feel different by their compatriots. This is evident in the lack of a common language or term to describe the North African second generation (Kastoryano 2006; Murray 2006). For example, the term étranger (foreigner) is often used to refer to the North African second generation (and immigrant-origin populations more generally), even though they were born in France (Ribert 2006; Silverman 1992; Stolcke 1995; Tin 2008). While I use the terms "second-generation North African immigrant," "second-generation maghrébin immigrant," "children of maghrébin immigrants," and "the French North African second generation" interchangeably throughout this book when referring to this population, there is no commonly agreed-upon term (such as an equivalent to African American, for example). ${ }^{41}$ They are often distinguished from Français de souche, though they are also native French. They are also frequently referred to as Muslims, although this privileges a religious identification over other identifications and presumes that every North African origin individual claims a Muslim identity in an identical way, or even at all (Alba and Silberman 2002). The term beur has also been used, though it is historically complicated. Beur, a slang term that is a partial anagram of the word arabe, was conceived in the Parisian banlieues by children of North African immigrants to challenge the negative connotations associated with being Arab (Begag 1990). However, the term beur grew to have a negative connotation as well, as it became attached to negative representations of the banlieues and their residents (Hargreaves 2007)..$^{42}$ Part of the complication regarding their simultaneous visibility and invisibility rests in the French colonial legacy in which the descendants 
of maghrébin immigrants were never supposed to be part of France (Sayad 2004; Silverstein 2008).

The largest survey of France's second generation, the 2009 joint Institut national d'études démographiques (National Institute of Demographic Studies, or INED) and INSEE study, Trajectoires et origines, found that 37 percent of second-generation Moroccan and Tunisian immigrants and 39 percent of second-generation Algerian immigrants, aged eighteen to fifty, had sometimes or often experienced unequal treatment or discrimination in the five years prior to the study. In addition, there exists a strong mismatch between individuals who feel French and those who perceive that others see them as French. When asked whether they feel French, about 70 percent of second-generation maghrébin immigrants indicated that they do, but about 43 percent also feel that their "Frenchness" is denied by others, as Frenchness is based on rather on a restricted vision of who "looks French" (Simon 2012, 13). This finding suggests the racial and ethnic parameters that define who is in fact accepted as French. This book is an ethnographic complement to this survey data. Moreover, I demonstrate how the source of the dissonance Simon (2012) identifies lies in how the North African second generation is denied cultural citizenship because of its racial and ethnic origins.

Other surveys have revealed the pervasiveness of discrimination facing the maghrébin second generation, which historian Tyler Stovall refers to as "a selfdestructive threat to France's racial status quo" (2003, 354). ${ }^{43}$ In 2008 the Centre national de la recherche scientifique (National Center for Scientific Research, or CNRS) conducted a study of ethnic profiling by the police in Paris and found that those who appeared to be of North African origin were at least 7.5 times more likely than whites to be stopped (OSI 2009). ${ }^{44}$

Other research on the North African second generation has focused on disadvantage inherited from the first generation, particularly in terms of specific outcomes, including educational attainment and employment prospects and relative disadvantage vis-à-vis whites. For example, many individuals of North African origin experience discrimination in employment, especially hiring, which they perceive as based on their name, skin color, or residential location-all seen as proxies for ethnic origin (Silberman 2011). The North African second generation is less likely than whites to have professional types of work and is to more likely to have a lower average annual income than whites (Lombardo and Pujol 2011). Overall, the quality of life of the North African second generation (as defined by poverty rate and unemployment) is worse than the quality of life of whites and children of European immigrants (Lombardo and Pujol 2011). ${ }^{45}$

Using data from the EHF, Meurs et al. (2006) compare the labor force participation of the first generation with the second generation. Based on measures such as access to employment, occupational status, and access to jobs in the civil sector, they find that although the second-generation experiences less occupational 
segregation overall than the first, they persist in experiencing high unemployment rates and low job security relative to whites. ${ }^{46}$ According to Meurs et al. (2005), having a maghrébin background makes someone 2.5 times more likely to be unemployed than if someone is white (controlling for educational attainment). Similarly, according to a 2011 report by the Haut Conseil à l'intégration (High Council for Integration, or HCI), ${ }^{47}$ second-generation immigrants of non-European origin were twice as likely to be unemployed as other citizens. This disparity exists even for those individuals who are skilled, qualified, and well educated (Barou 2014).

Moreover, even for those children of maghrébin immigrants who are gainfully employed, a glass ceiling still exists (Belmessous 2007). They are more likely than whites to hold jobs beneath their educational attainment level. The disadvantage that second-generation North African immigrants experience vis-à-vis whites cannot be explained entirely by differences in levels of educational attainment (Lutz et al. 2014; Silberman et al. 2007)..$^{8}$

As of 2003, about 15 percent of second-generation North African immigrant men, and about 23 percent of second-generation North African immigrant women, held salaried jobs. In this book, I focus on this population, or what some have termed the beurgeoisie, a play on the slang term for children of North African immigrants, beur (Hargreaves 1998; Wenden and Leveau 2001). These individuals have experienced upward mobility vis-à-vis their immigrant parents and have achieved middle-class status in terms of educational and professional accomplishments.

\section{MIDDLE-CLASS, YET MARGINALIZED}

By focusing on the middle-class, I argue that being incorporated into French society and being accepted as French by others is not a question of professional success, educational attainment, or adhering to Republican ideology. Rather, France has a growing group of citizens who, despite doing everything right, cannot achieve full membership in French society. This demonstrates the limitations of citizenship within a democratic context, wherein difference based on ethnic status reveals a more dynamic notion of who is included in the Republic and who is not. Focusing on the middle-class is both a theoretical and empirical contribution, as previous research has focused more heavily on how working-class and impoverished immigrants and their children are marginalized and less on how "successful" children of immigrants face similar issues despite their upward mobility. Middle-class status does not provide automatic inclusion into mainstream society.

By mainstream or mainstream society, I am applying Alba and Nee's (2003, 12) definition: "interrelated institutional structures and organizations regulated by 
rules and practices," as well as "practices that foster assimilation, that is, backgrounding ethnic origins of 'included' ethnic minority" members. ${ }^{49}$ So in this context, mainstream society is hegemonic and refers to what is often outside of respondents' maghrébin cultural world-including what they learn in school, what and whom they see represented in the media, and whom they see represented at various levels of government. More generally, mainstream society may be thought of as where the majority population feels at home, or "where its presence is taken for granted and seen as unproblematic" (Alba and Foner 2015, 5).

In terms of middle-class status, I focus on respondents' educational attainment and professional employment. Following a Weberian perspective, social scientists have measured a middle-class status based on both objective and subjective factors, including income, education level, shared values and goals, and prestige (Feagin 1991; Stearns 1979; Urry 1973; Wacquant 1991). Middle-class status is not just a socioeconomic location, but also a social status (Weber [1922] 1978). Subjective factors related to class include the ideas "people have and hold about their own social positions, ideas that may not be systematically arrived at or as exclusively tied to hard and fast economic charts, ideas that can even give substantial weight to noneconomic criteria of social worth" (Jackson 2001, 128-29). The symbolic boundaries around middle-class as a category are also important, as the middleclass is also defined by what it is not (Wacquant 1991).

This echoes research measuring the African American middle-class and minority middle-class populations more generally (see Marsh et al. 2007). For example, Pattillo-McCoy $(1999,13)$ uses "a combination of socioeconomic factors (mostly income, occupation, and education) and normative judgments (ranging from where people live, to what churches or clubs they belong to, to whether they plant flowers in their gardens" in her exegesis of Chicago's black middle-class. Furthermore, Landry and Marsh (2011) emphasize a Weberian approach to measuring and understanding middle-class populations, which are therefore constituted by individuals with white-collar employment, a term coined by C. Wright Mills ([1951] 2002) (see also Feagin 1991).

In my focus on "middle-classness," I emphasize how respondents perceive themselves as middle-class individuals and make meaning in their everyday lives. Achieving a middle-class status, in France, the United States, and other societies, is a benchmark for having made it. Middle-class status, including being educated and holding a professional job, is often framed as an aspiration, a step closer to being an ideal citizen.

Middle-class minorities are often positioned as examples of successful assimilation, or full integration within mainstream society. As Landry and Marsh (2011, 374) point out: "For a minority group, the development of a middle-class marks a decisive moment in its development, affords access to improved life chances as well as membership in the class that provides the brain trust for industry and 
government. In addition, a minority middle-class serves the indispensable role of leadership in the struggle against discrimination and oppression that is often the experience of its members."

Yet the middle-class of a majority group differs from the middle-class of a minority group (Hout 1986), or a "subaltern middle-class," which Pandey (2009, 322) defines as "middle-class groups that emerge from, and remain in various ways closely tied to, long-stigmatized lower-class and underclass populations." Race and ethnicity remain salient regardless of socioeconomic position. Again, the black middle-class is an instructive referent, as its members remain distinct from their white middle-class counterparts in the United States. In the Black Bourgeoisie, African American sociologist E. Franklin Frazier (1957) highlighted the particular cultural and political circumstances of the black middle-class. And we now know that the black middle-class is not as stable as other middle-class populations, owing to continual systematic racism (S. Collins 1983; Gregg 1998; Pattillo-McCoy 1999). Journalist Ellis Cose highlights the "permanent vulnerability of status" (1994, 41), as black middle-class professionals find that their middle and upper-middle-class statuses do not shield them from race-based marginalization..$^{50}$

As the black and white middle-classes remain distinct in the United States (Marsh et al. 2007), so, too, do the white and the North African-origin middleclasses in France. ${ }^{51}$ Middle-class status does not confer the same advantages, both real and symbolic, on North African-origin individuals as it does on their white middle-class counterparts. The fact that socioeconomic status does not ameliorate the distinctions among individuals further reveals how France is permanently hindered by its racism and colonial past.

Their stigmatized ethnic and racial identity, in tandem with a middle-class, or economically advantaged, status, means that minority middle-class populations experience a particular tension. Their middle-class status and accomplishments take them only so far-because they are racial and ethnic minorities. They have to strategically navigate this insider-outsider position between stigma and status (Clerge 2014), or as Hicham, a twenty-nine-year-old of Moroccan origin who lives in the banlieue of Poissy, puts it, between "the two sets of codes-French and maghrébin. We understand them both."

Achieving middle-class status is thus not a panacea for resolving social exclusion. This is true for the North African second generation. Such status does not do the same work for these individuals as it does for their white counterparts. They realize their middle-class status mostly in relation to their working-class counterparts and immigrant parents, yet they feel excluded from the full privileges associated with a middle-class status. As I later discuss, the maghrébin second generation draws boundaries that, depending on the context, both distinguish them from and include them in the economically disadvantaged segment of the maghrébin second generation. Respondents are conscious of how their everyday lives are both 
similar and markedly different from those of their working-class counterparts (this is one example of how respondents make sense of their social locations).

French demographer Patrick Simon (2003) identified three paths for France's second generation: a reproduction of the positions of the first generation; a successful upward social mobility through education; or a mobility hindered by discrimination. In this book, I focus on the second category-individuals who have achieved upward mobility through education yet simultaneously feel hindered by discrimination and exclusion in terms of their actual place in mainstream society. This is different from positioning the maghrébin second generation as successfully assimilated, as Loïc Wacquant (2007) attests, which I discuss further in chapter 3.

By marginalization, I am referring not just to the denial of access to material resources, but also what Cathy Cohen $(1999,38)$ terms the "stigmatized or illegitimate social identity that such groups have in the larger or dominant society." Marginalized groups are distinguished by "the pervasive way in which ideologies or myths which explain, justify, and recreate their secondary position become institutionalized throughout society" (43)..$^{52}$ This stigmatized or illegitimate identity is born out of the French colonial context. I posit here that children of North African immigrants - even those who are middle-class_-are framed as stigmatized or illegitimate with respect to having a rightful place within France, and must develop a framing of their marginalization outside of a sanctioned language to discuss racial and ethnic difference. Throughout this book, I discuss how the secondary position of the maghrébin second generation is reinforced through both individual-level interactions and macrolevel structures and practices. Middle-class individuals often experience more discrimination or feel more marginalized than their working-class counterparts (Cose 1994; Tomaskovic-Devey et al. 2005). Educated and middleclass second-generation immigrants are more likely to report higher levels of discrimination than immigrants and less educated immigrant-origin individuals (Fleischmann et al. 2011). Research has shown that the more highly educated North African immigrant-origin individuals are, the more the complaints of discrimination (Silberman et al. 2007). Marginalization is often exacerbated for middle-class individuals because they feel as though they have done everything right.

I frame the North African second generation as "citizen outsiders", a term that Cathy Cohen (2010) uses to characterize the precarious social locations of African American youth. Cohen considers the degrees to which African American youth feel like full members of the citizenry as a way of understanding how marginalized individuals relate to the state and how that complicates the relationship among race, citizenship, and belonging. This is reminiscent of Patricia Hill Collins's (1986) notion of the "outsider-within" and Tina Campt's (2005) notion of the "otherwithin," which conceptualize how individuals may be simultaneously members of a society yet kept on its margins (and the simultaneous insider and outsider positions they hold). The middle-class North African second generation is both 
included and excluded from the citizenry-they have made it, so to speak, but only to a point, as they are continually reminded of how their citizenship is suspect and often questioned by others. This is reminiscent of W. E. B. DuBois's notion of "double consciousness," referring to how African Americans must negotiate two seemingly different and unreconciled identities-American and black, as articulated in his Souls of Black Folk: Essays and Sketches. ${ }^{53}$ The North African second generation must bridge the different cultural worlds of France and the Maghreb. They have what DuBois has termed a "second-sight," a way of looking at oneself through the eyes of others.

The concept of a minority group based on identity is antithetical to the ideals of French universalism and Republicanism, which recognize individuals and not groups. There is no framework for acknowledging racial and ethnic minority groups and incorporating them within France's national community. Citizen Outsider grapples with this paradox-that France does not acknowledge racial and ethnic minorities yet marks those individuals as different. If these middle-class individuals feel excluded from mainstream society, their socioeconomic status is not the explanatory variable. Their racial and ethnic origin is.

\section{FRANCE'S RACIAL PROJECT:}

\section{THE CONTINUING SIGNIFICANCE OF RACE AND ETHNICITY}

Asserting the significance of race and ethnicity is provocative in France, as under Republicanism, being French is supposed to trump all markers of difference. Despite the promotion of a colorblind ideology and an official masking of possible and real ethnic differences, the state has a narrow definition what of it means to be French, a definition with particular racial and ethnic underpinnings. Specifically, white supremacy structures the definition of who is French. To the extent to which race is mentioned, it is not as a social construction, but rather a physical definition of human groups, so acknowledging race propagates racism and furthering divisions among humans (Keaton 2010).

Race and ethnicity are salient in marking boundaries of inclusion and exclusion in France's "racial project." In this racial project, "racial categories are created, inhabited, transformed, and destroyed" (Omi and Winant 1994, 55). A racial project signifies differences among individuals and creates a "racial common-sense" (55), or a way of understanding populations seen as "other," which is continually made and remade (Silverstein 2008). This racial common sense is created in a seemingly colorblind society. The North African second generation is racialized as "other" (Kastoryano and Escafré-Dublet 2012; Winant 2001), and it is this process that prevents them from being fully included in France's "imagined community" (Anderson 1991). Racialization is revealed through citizenship laws, mechanisms of state control, external ascription, criminalization, spatial segregation, popular 
and political discourse, and daily interactions (Weiner 2012). The French context reveals how these processes of racialization can occur in a supposedly antiracial or colorblind society and without legally substantiated boundaries around racial and ethnic categories. This contrasts with the United States, where race and ethnicity, as measured in the census, have had specific, though evolving, definitions as categories dependent on the larger societal contexts (for example, the "one-drop rule" as a determination of black identity). French Republicanism merely obfuscates differences; it does not minimize or eliminate them..$^{54}$

Even though race as a term exists in the French language, the National Assembly suppressed its use in legislation in 2013 (Beydoun 2013). It is this context that makes race in France both necessary and difficult to discuss. Specifically, race "signifies and symbolizes social conflicts and interests by referring to different types of human bodies" (Omi and Winant 1994, 55), which "form a distinctive stigmata of inferiority" (Keaton 2010, 106). It is a way of making meaning out of differences that are historically and socially informed. I center France's colonial history and postcolonial legacy in understanding the experiences of nonwhite individuals. As I demonstrate, North African-origin individuals are read as nonwhite through a variety of markers. "Skin color, hair, features, language varieties, and by extension family name, religion, in short, people's ways of being and knowing-have longstanding social meanings in France, underpinned and enlivened by ideologies and policies acting on them" (Keaton 2009, 108). ${ }^{55}$ Constructing Frenchness as white, and French identity as a white one, is part of this racial project, which dates from the construction of the nation itself. French culture is portrayed as an unchanging, homogenous entity.

To clarify, I am not using ethnic origin or group in opposition to race, as I do not want to suggest that ethnic origin is not racialized in France..$^{56} \mathrm{I}$ use ethnic origin in the Weberian sense as the subjective belief in a group's common descent, cultural, and historical experiences (Weber [1922] 2013). ${ }^{57}$ North African-origin individuals are constructed as a separate ethnic group (as having ethnic origins in the Maghreb) and racialized as nonwhite. These processes are coconstitutive of each other.

As such, this book is in conversation with research on racial and ethnic identities, including how immigrant-origin individuals negotiate their identities in light of existing racial and ethnic hierarchies, and how individuals are shaped by their experiences of racial and ethnic marginalization in how they see themselves (see K. Hall 2004; Sharma 2010; Warikoo 2004; Waters 1999)..$^{8}$ They respond to both the ethnic identities of their immigrant parents from their home country and the nation-based identities in their current environment (Chong 1998; Cornell and Hartmann 2007; Eid 2008). ${ }^{59}$ Identity based on ethnic origin relies on an interplay between external and internal self-identification, subject to various structural constraints. ${ }^{60}$ 
Throughout this book, I demonstrate how race and ethnicity remain salient not only at an individual level but also as a macrolevel project structuring boundaries of inclusion and exclusion around full citizenship. Race and ethnicity are inextricable with nationhood and nationalism, as the construction of race and ethnicity occurs simultaneously with the construction of the nation (Brubaker 2009). As the experiences of my respondents reveal, belonging in France is circumscribed by race and ethnicity, and being included or accepted depends upon racial and ethnic status. In France, one's racial and ethnic status, or being nonwhite, is a barrier to full cultural citizenship, a framework upon which I later elaborate.

Beyond denying race as a term, common discourses about race and ethnicity in France say that race does not exist; that race is less significant in France than in the United States; and that France is a colorblind society (Ndiaye 2008). Understanding France's racial project requires understanding the salience of race and ethnicity in Europe more broadly. Race structures the nation-state yet is framed as existing everywhere but in Europe (Goldberg 2006). Racism is discussed solely in relation to the Far Right, not as a boundary against "those historically categorized as nonEuropean, as being not-white" (347) ${ }^{61}$ Within France, in place of a discourse on race and ethnicity, scholars have traditionally focused on class and socioeconomic status as the explanatory variable for social marginalization in French society (Amiraux and Simon 2006; Ndiaye 2008). This scholarly focus does not acknowledge France's history of slavery or colonial legacy, nor the structural nature of racial and ethnic relations, and rejects race and ethnicity as analytical categories in social scientific inquiry.

A few scholars have argued for increased attention to race and ethnicity in France, and how they shape daily experiences and life outcomes. In La condition noire: Essai sur une minorité française (The black condition: Essay on a French minority) (2008), French historian Pap Ndiaye excavates France's black population and demonstrates its paradoxical status as simultaneously visible and invisible as a minority. This visibility of a minority depends upon "the presence of phenotypical characteristics that racially or ethnically characterize those persons concerned ... that is, people whose supposed ethnoracial membership can be deduced from their appearance" (Ndiaye 2008, 57-58). The black condition in France is one of a transnational blackness, or a product of social relations that characterizes the shared experience of being black (or at least regarded as black by others). In chapter 5 , I discuss how this extends to maghrébin-origin individuals in France, who often assert identities situated and informed by blackness as it relates to black populations worldwide. Moreover, France's blindness to race is coupled with race-based assumptions that lead to a consciousness of race, and therefore antiblack racism, which masks itself in different institutions (Keaton 2010).

However, Michèle Lamont (2002), in The Dignity of Working Men: Morality and the Boundaries of Race, Class, and Immigration, argues that France's Republican 
and colorblind ideology enables not an antiblack racism but a cultural racismone that distinguishes between individuals seen as native French and immigrantorigin individuals who are not. This cultural racism is a remnant of France's colonial history and is often directed toward immigrants from North and sub-Saharan Africa. Therefore, when individuals draw symbolic boundaries that exclude those of immigrant origin, they can claim to do so based on cultural differences, rather than on racial or ethnic ones.

Yet the focus on cultural racism in France misses how "culture" is code for race and ethnicity, historically and in the present. French culture and identity are implicitly and explicitly framed as white (Constant 2009). Culture is therefore a social and symbolic boundary (Lamont and Molnar 2002). ${ }^{62} \mathrm{~A}$ focus on cultural distinction ignores the structural dynamics at play in the marginalization of maghrébin immigrants and subsequent generations. In addition, this focus ignores how even maghrébin-origin individuals-such as my respondents-who do not necessarily see themselves as different from their white counterparts are still treated as different.

Racial and ethnic minorities can feel as French as anyone else but still not be treated as such or accepted as French by others. Therefore, their difference is one that is assigned, and one from which they cannot escape. Focusing on culture instead of race also sustains the denial of race and ethnicity and furthers the myth of colorblindness in France (Keaton 2009; Ndiaye 2008). This resembles how ideologies of colorblindness in the United States not only perpetuate racism but also minimize its importance (Bonilla-Silva 2013). Minimizing race, and therefore racism, perpetuates the idea that race and ethnicity as statuses do not affect life chances or outcomes. This allows France to continue to ignore the consequences not only of its colonial past but the racial and ethnic dimensions of its national identity. Because of the emphasis on colorblindness in Republican ideology, marginalization based on race and ethnicity is harder to combat.

As I discuss in chapter 4, the social location of North African-origin individuals relies on the distinction between the legal and cultural dimensions of French identity - that is, between being a French citizen and being accepted as French by others. Individuals like Abdelkrim can assert that they are as French as any other French person, yet because of the boundaries around this identity, they find that this claim to French identity is not easily accepted or legitimated by others. The boundaries around the identity of native French render maghrébin-origin individuals "unassimilable" and marginalized regardless of their socioeconomic status. I argue that the boundaries structuring who is accepted as French continually exclude North African-origin individuals and remind them that they are not. As social and cultural barriers, these boundaries are racial and ethnic demarcations of belonging within France.

As culture is a euphemism for race, so too is religion-in this case, Islam. While previous research has argued that religion is the basis for the construction of 
symbolic boundaries between "us" and "them" (Zolberg and Woon 1999), I argue that religion is also code for racial and ethnic boundaries (Barth 1969). Therefore, race is not a mask for something else; rather, religion, culture, and other factors are masks for race. When maghrébin-origin individuals are deemed too culturally different from other French individuals, it is not because of their affiliation with Islam (which is nonetheless heterogeneous and contextual); it is because of their status as "ex-colonial citizens of color," to borrow Hall 2004's terminology for secondgeneration Sikhs in London. Abdelkrim and others are marginalized not because of their religious identity or practices but because of their maghrébin origins (Beaman 2016). I discuss respondents' marginalization as Muslims in chapter 3.

The maghrébin second generation can assert a French identity, yet because of the ethnicized and racialized nature of French identity, these North African-origin individuals are assigned another racial or ethnic identity: nonwhite. Even if France does not explicitly recognize distinct racial and ethnic categories, I argue that it recognizes French as a specific identity category that is not accessible to minorities of color. While race and ethnicity do not exist as something to be measured or quantified in French society, they operate in everyday life, as the ethnoracially marked experiences of my respondents reveal. As such, a consciousness of racial and ethnic differences exists simultaneously with a denial of race and ethnicity. Throughout this book, I discuss how individuals interpret and respond to these boundaries that exclude them. Furthermore, these respondents inhabit a tenuous social location, in that they fit within the confines of the social boundary of citizenship, but not within the symbolic boundaries around French identity. They are citizens but are not made to feel like citizens. They are not treated like citizens. Because of the symbolic boundaries around national identity, in this case, Frenchness, boundaries based on racial and ethnic origin serve to marginalize immigrant-origin individuals.

\section{CULTURAL CITIZENSHIP AND RACIAL FORMATION}

That immigrant-origin individuals are continuously marginalized-which is linked to ethnic-minority status-challenges what would be expected in French Republican society. The French Republican model rejects any implication of a distinction between culture and citizenship, meaning that to be a French citizen is to be French, or to be French is to be a French citizen. Comparing national boundary patterns of the United States and France, Lamont argues that citizenship serves as a salient boundary between in-groups and out-groups, or "us versus them" in France (Lamont 1995; see also Brubaker 1992 and Lamont 2000). However, I demonstrate how simply having French citizenship is not a sufficient marker of who is regarded as French and who is not, as individuals who are citizens remain excluded from mainstream society. ${ }^{63}$ 
I show that citizenship does not confer the same benefits on other populations as it does on whites, as children of immigrants, who are racial and ethnic minorities, are marginalized to degrees similar to their immigrant parents. They are denied cultural citizenship because of their North African origins and because they are not white. This denial of cultural citizenship challenges a French exceptionalism regarding marking difference among citizens. What exists in France is citizenship without societal inclusion, an "ambiguous citizenship" (Cain 2010).

My framework of cultural citizenship emphasizes how citizenship operates for marginalized populations, who despite being formal legal citizens are nonetheless not fully included in the citizenry. Cultural citizenship focuses on what would allow an individual to traverse the cultural-symbolic boundaries defining a particular national community and identity and be accepted as a full member (Beaman 2016b). Insofar as cultural citizenship is a claim, it is a claim to full societal belonging by fellow members of one's community rather than a claim to a specific set of rights. Being denied cultural citizenship denotes an impaired civic status (Meer 2010). Furthermore, cultural citizenship means being fully included in society, despite one's difference from others. When children of North African immigrants indicate that their fellow citizens do not consider them as French as they are, they are expressing how their fellow citizens are denying them cultural citizenship. These are individuals born in France who insist upon their Frenchness and are still denied it. When respondents seek to be viewed as French by others, they are ultimately making a claim for cultural citizenship-a claim to be regarded as a legitimate member of the French mainstream or a part of French culture.

I build upon cultural anthropologist Renato Rosaldo's formulation, based on Latinos in the United States and used to resist dominant racialized power structures. He speaks of "the right to be different (in terms of race, ethnicity, or native language) with respect to the norms of the dominant national community, without compromising one's right to belong.... [This] includes and goes beyond the dichotomous categories of legal documents, which one either has or does not, to encompass a range of gradations in the qualities of citizenship (Rosaldo 1994, 57). He argues that cultural citizenship presumes a universal citizenship based on white men, where those who are different are excluded. Latino identity has been shaped by experiences of discrimination and efforts toward full inclusion in American society. The denial of cultural citizenship to Latinos in the United States, as well as to the North African second generation in France, reveals how race and ethnic origin keep certain populations on the margins of mainstream society. Cultural citizenship challenges the stigmatization and marginalization of different populations that are supposedly antithetical to the laws of the nation-state. ${ }^{64}$

Traditional conceptions of citizenship have a culturally normative dimension that makes some legal citizens more or less accepted than others. ${ }^{65}$ However, it 
is this nonlegal dimension that often goes unacknowledged. Cultural citizenship acknowledges the relationship between culture and citizenship and considers citizenship beyond its legislative status (Bloemraad 2015; Delanty 2002; GarcíaSánchez 2013; Vega and van Hensbroek 2010), including how it creates both full and second-class citizens. It also allows us to unpack how citizenship is socially and culturally constructed and how race, class, and immigrant status are barriers to full societal acceptance (Ong 1996). Specifically, "citizenship is both a cultural and anti-cultural institution. . . Citizenship positions itself as oppositional to specific cultures, even as it is constituted by quite specific cultural values" (Volpp 2007, 574). The cultural attachments associated with being of North African origin are positioned as oppositional to being French (Lamont 2002). There is only one way to be French (Volpp 2007).

Difference is seen in relation to a normative center, in which all other cultures are on the periphery. As legal scholar Leti Volpp (2000) argues, what is viewed as cultural or culturally different is often what is associated with people of color and other minorities. In this way, culture is closely linked to race and ethnicity. Once we recognize this connection, we can fully consider how culture is code for race and ethnicity, particularly in contexts where explicit discussion of race and ethnicity is not permissible. It is therefore radical to think of cultural citizenship in the French context, as it implies that citizenship status is not the only marker of difference. For marginalized groups, citizenship is more precarious (Glenn 2011). Racial and ethnic minorities are often denied cultural citizenship or full belonging in society (Bonilla-Silva and Mayorga 2011; Cohen 2010) ${ }^{66}$

This denial of cultural citizenship is evidence of France's racial project. By focusing on cultural citizenship as an explanatory framework for marginalization, I specify how citizenship operates as a marker of difference, through its relationship to race and ethnicity (Beaman 2015a). We cannot understand citizenship in France without acknowledging its racial divides (Silverstein 2008). Nonwhite citizens are denied cultural citizenship. Citizenship as a racialized status is fragmented, in that people who are formal citizens are informally excluded from full societal inclusion. Citizenship therefore exists as a "surveilled performance of national belonging" (25), in which whites reinforce boundaries of who really gets to belong. ${ }^{67}$ Citizenship in this way is better understood as local, everyday practices (Brettell and Reed-Danahay 2012; Silverstein 2008).

This resembles how second- and subsequent-generation Asian and Latino immigrants in the United States are considered "perpetual foreigners" (Wu 2001), often questioned about where they are from and having to prove their "Americanness" (Zhou and Lee 2007). They are still pressured to identify based on their ethnic origins, even as they assert that they are American (Zhou and Lee 2007). Though they were born and grew up in the United States, only a partial assimilation is possible. They are often asked, "Where are you really from?" thereby 
drawing boundaries determining who an American is and reinforcing that they are not truly American (Wu 2001).

\section{THE RESEARCH}

This book is based on longitudinal ethnographic research I conducted primarily during the 2008 to 2009 academic year, including semistructured interviews in French with 45 adult children of maghrébin immigrants living in the Parisian metropolitan region beginning in fall 2008 (I discuss further details of this methodology in the methodological appendix). I was initially interested in exploring what it means to be a minority, and how minorities understand their social locations in French society. I moved to Paris in fall of 2008 for this purpose.

Recruiting interview respondents proved more difficult than I anticipated, because of my outsider status, and I used snowball sampling after contacting various organizations and associations for potential respondents. My respondent sample includes twenty-four men and twenty-one women. ${ }^{68}$ Respondents range in age from twenty-four to forty-nine years old (the average age is thirty years old). Twenty-five of them (about 55 percent) are of Algerian origin; twelve (about 26 percent) Moroccan; and eight (17 percent) Tunisian. Three respondents are products of mixed-race relationships, meaning one parent is white and the other is maghrébin. All respondents live in the Paris metropolitan region, or Ilede-France. Thirty-five percent of respondents live in Paris, and 65 percent live in the banlieues, mostly in the inner-ring départements (in France a department is a major administrative subdivision or branch of government) of Seine-SaintDenis, Val-de-Marne, and Hauts-de-Seine. All respondents have French citizenship, and about a third of them have dual citizenship (the other being in their respective maghrébin countries of origin). ${ }^{69}$ Most respondents' parents emigrated from the Maghreb between 1950 and 1970, primarily for economic reasons. Many of these parents have low levels of educational attainment, often not past middle school, speak little French, and communicate mostly in Arabic or Berber (Kabyle). Usually, the fathers worked in low-skilled jobs, such as construction and factory employment, while mothers were homemakers or did domestic labor.

In marking respondents' middle-class statuses, I focus on respondents' educational attainment levels and professional statuses. With regard to educational attainment, I focus on those who passed the baccalauréat (bac) exam and attended college (whether or not they actually graduated). In terms of employment, I focus on those who have professional types of employment-including the French socioprofessional categories of cadre (salaried or executive-level employment) and professions intermédiaires. ${ }^{70}$ Some of these jobs include technical director, journalist, doctoral student, lawyer, banker, human resources associate, hospital director, high school teacher, insurance agent, governmental administrator, information 
technology consultant, public relations consultant, and television reporter. I therefore use a combination of occupation and educational attainment as indicators of the socioeconomic locations of my respondents (Weber [1922] 2013; see also Landry and Marsh 2011).

In addition to these interviews with forty-five middle-class maghrébin-origin individuals, I conducted nine months of participant observation with some respondents. I went to networking events, both professional and social, with my some of my respondents. For example, I went to a book-signing event with one of my respondents at a literary festival for maghrébin-origin authors. I also attended various débats (panel discussions) and lectures on relevant topics. ${ }^{71}$ I spent time with my respondents' families and visited their workplaces. In the process of contacting various organizations and associations for respondents, I connected with the Nanterre Association, a community organization in the western banlieue of Nanterre (about ninety minutes from Paris by commuter train), and was able to supplement my interviews with participant observation there. The organization, located in an impoverished community in Nanterre, serves the local neighborhood by offering educational, cultural, and social activities, including field trips to Paris monuments, panel discussions, and after-school tutoring.

My position as an outsider, not only as a researcher but also as a native-born American and a black woman, undoubtedly shaped how my respondents perceived me. I discuss the role of my identity further in the methodological appendix. While I was an outsider in some ways, many respondents also perceived me as an insider - as we both shared the status of racial and ethnic minority (see also Khanna 2011). These perceptions of my personal biography, particularly my racial and ethnic identity, were often invoked in interactions with respondents, most often to draw symbolic boundaries with or against their own identity. As I discuss in chapter 5, these boundaries had implications for studying race and ethnicity from a different national context.

\section{OVERVIEW OF CHAPTERS}

In the next chapter, "Growing up French? Education, Upward Mobility, and Connections across Generations," I focus on my respondents' childhood experiences growing up in France with immigrant parents and how they learn to navigate the different cultural worlds of home and school. I situate growing up French as a question because respondents relate how their place within France was first questioned at an early age. This is reminiscent of the experiences of second-generation immigrants in other societies (Alba and Waters 2011; Essed 1991; Kasinitz et al. 2004; Portes et al. 2011; Waters 2000) but also complicated in the French context because racial and ethnic categories are not acknowledged as meaningful bases for identity. There are no identity "options" (Waters 2000). I also discuss how 
respondents navigate these different cultural worlds throughout their education and how they contributed to their upward mobility in adulthood.

In chapter 3, "Marginalization and Middle-Class Blues: Race, Islam, the Workplace, and the Public Sphere," I examine experiences and perceptions of discrimination and marginalization across different domains. I discuss how respondents frame and make sense of these experiences, and how their middle-class status shapes these meaning-making processes. Chapters 2 and 3 establish how this segment of the maghrébin second generation is marginalized because of its North African origins. Chapters 4 and 5 address the impact of this on their consciousness and identity as minorities.

In chapter 4, "French Is, French Ain't: Boundaries of French Maghrébin Identities," I unpack how individuals identify and how being French and having North African origins are implicated in their self-identities. I build upon previous examinations of ethnic identity for immigrant-origin individuals and show how respondents negotiate their identities vis-à-vis their maghrébin ethnic origin. I focus on a continuum ranging from a hyphenated and combined identity, seeing oneself as neither French nor maghrébin, to a singular identity as only maghrébin. Republicanism constrains the identity options available to this population and creates the tension between assigned versus asserted identities. I also interrogate how children of North African immigrants interpret French Republicanism as an ideology, as well as the boundaries determining what it means to be French. I revisit the concept of cultural citizenship to consider how Republicanism as ideology and in practice creates boundaries defining French as an identity that forces these individuals to occupy a liminal position in relation to mainstream society.

In chapter 5, "Boundaries of Difference: Cultural Citizenship and Transnational Blackness," I consider how this minority population invokes blackness, based on the experiences of black populations elsewhere, in making sense of their social locations. Considering how the maghrébin second generation relates to other black populations, such as African Americans, allows us to consider how notions of diaspora and transnational blackness apply not only to blacks in France but to North African-origin minorities in France as well.

Finally, in the conclusion, "Sacrificed Children of the Republic?" I review how the racial and ethnic underpinnings of French Republicanism disallow even "successful" children of immigrants to ever truly be viewed as French by others. I also discuss how cultural citizenship increasingly becomes a relevant question in multicultural and plural societies. I consider the important lessons provided by the French example in drawing conclusions about the role of difference, race, and ethnicity in the twenty-first century. I further consider the implications of this study for the future of France, particularly in light of the massacre at the offices of Charlie Hebdo and the November 2015 terrorist attacks. 
I first moved to Paris to conduct this research amid the campaign and first presidential election of Barack Obama in fall 2008. As the debate of whether the United States had entered a postracial era raged on, across the Atlantic Ocean in France was an example of a society struggling with how colorblind ideologies operate in practice. The fever of Obama's presidential campaign and election spread to France (Benia 2009; Erlanger 2008), where it raised the question as to whether France could produce its own Obama. I discussed this question one afternoon with Sabri, a thirty-year-old of Tunisian origin:

It will be hard, but we have to find our own French Barack Obama. There might be more than one... . But first we must help those who are still stuck in the past. Colonialism is still in the spirits of some people. Meaning when I tell you that people treat us like children, for me that's because of colonialism. Today people think children of immigrants in France are still strangers. That we are not really French. So we have to show them that they are not superior, that it's a question of equality. Once they see us as equal to them, once we have that relationship, then things will change, but now, today, that's how it is.

As I finished this book, Donald Trump was elected president of the United States and Far Right politicians have increased in popularity throughout Europe, including in France, where Marine Le Pen of the Front National (National Front) launched a presidential campaign on the claim that France is losing its identity and will soon be unrecognizable (though she made it past the first round of the election, she lost the second round, nevertheless winning 34.5 percent of the vote). If France is to move in another direction and produce a president who is an ethnic minority like Obama, if it is to fully incorporate individuals who are legacies of its colonial empire, it will have to grant all its members, including the forty-five I discuss in this book, cultural citizenship. 